\title{
Liquefaction in Palu: the cause of massive mudflows
}

\author{
Abdul Jalil ${ }^{1,4^{*}}$, Teuku Faisal Fathani ${ }^{1,3}$, Iman Satyarno ${ }^{1,3}$ and Wahyu Wilopo ${ }^{2,3}$
}

\begin{abstract}
The 7.5 $M_{w}$ tectonic earthquake that hit Palu City on 28 September 2018 was followed by tsunami and liquefaction, triggered massive mudflows in Balaroa, Petobo, and Jono Oge areas. This study focuses on the generating factors of liquefaction such as the condition of soil lithology, depth of water table, the distance to the focal mechanism, and the thickness of soft sediment. Microtremor data, including the Horizontal Vertical Spectral Ratio (HVSR), geological condition, and borehole data, were examined to conduct the liquefaction analysis. The analysis results based on the microtremor data showed that the distribution of ground shear strain values in Palu City ranged from $0.75 \times 10^{-4}$ to $2.56 \times 10^{-4}$. The distribution of the locations of the liquefaction was correlated to the distribution of ground shear strain values. High ground shear strain values and a shallow groundwater level were discovered in Palu City valley, which indicates that liquefaction in Palu City will undoubtedly occur. The semi-empirical method confirmed that Balaroa, Petobo, and Jono Oge had undergone large-scale liquefaction at a maximum depth of $16 \mathrm{~m}$ below the ground level. The average peak of water runoff that generated the mudflow was estimated to be at $11.31 \mathrm{~cm}^{3} / \mathrm{s}$. Since the soil has loose soil grain with high water content, the soil will turn into a massive amount of mud during the liquefaction.
\end{abstract}

Keywords: Liquefaction potential, Microtremor, HVSR, Ground shear strain, Mudflow

\section{Introduction}

On September 28, 2018, an earthquake of $M_{\mathrm{w}} 7.5$ struck Central Sulawesi Province, Indonesia with the earthquake hypocenter located at a depth of $11 \mathrm{~km}$ and the geographic coordinate of $0.18^{\circ} \mathrm{S}$ and $119.85^{\circ} \mathrm{E}$. the earthquake had prompted extensive damages (Fig. 1) and mudflows in Palu City Valkaniotis et al. (2018), Mason et al. (2019). The mudflow covered the areas of Balaroa, Petobo, and Jono Oge, as shown in Fig. 1 b-d, respectively. The enormous life loss due to the liquefaction in Palu could probably be attributed to the three mudflows, which moved material within hundreds of meters downslope parallelly. Two of these mudflows originating as lateral spreads directly beneath the Gumbasa irrigation channel occurred at Petobo and Jono Oge (Fig. 1c, d). Meanwhile, the mudflow in Balaroa was located close

\footnotetext{
*Correspondence: abduljalil@mail.ugm.ac.id

${ }^{1}$ Department of Civil and Environmental Engineering, Faculty

of Engineering, Universitas Gadjah Mada, Yogyakarta 55281, Indonesia

Full list of author information is available at the end of the article
}

to the Palu Koro fault line, and it was interpreted that it fell along the fault as it was close to the fault line. The mudflow left severe damages on a large part of the soil on the gentle slopes of Palu City Socquet et al. (2019) within a distance of $1 \mathrm{~km}$ approximately. The damage of the Gumbasa irrigation channel triggered flash floods which turned into wave-like mudflows (Mason et al. 2019). The Gumbasa irrigation channel was an anthropogenic hazard of unexpected landslides in Palu that clearly demonstrated the need for more proactive assessment (Bradley et al. 2019).

The epicentral distance to the liquefaction site in Palu City was plotted in an image developed (Ambraseys 1988) based on the database regarding shallow earthquakes around the worldwide (Fig. 2). As shown in Fig. 2, the distance between Palu City and the epicenter of the $7.5 M_{\mathrm{w}}$ earthquake was $80 \mathrm{~km}$, which indicated consistency with the findings.

The Meteorological, Climatological, and Geophysical Agency (BMKG) reported that the earthquake that hit
Springer Open

(c) The Author(s) 2021. Open Access This article is licensed under a Creative Commons Attribution 4.0 International License, which permits use, sharing, adaptation, distribution and reproduction in any medium or format, as long as you give appropriate credit to the original author(s) and the source, provide a link to the Creative Commons licence, and indicate if changes were made. The images or other third party material in this article are included in the article's Creative Commons licence, unless indicated otherwise in a credit line to the material. If material is not included in the article's Creative Commons licence and your intended use is not permitted by statutory regulation or exceeds the permitted use, you will need to obtain permission directly from the copyright holder. To view a copy of this licence, visit http://creativecommons.org/licenses/by/4.0/. 


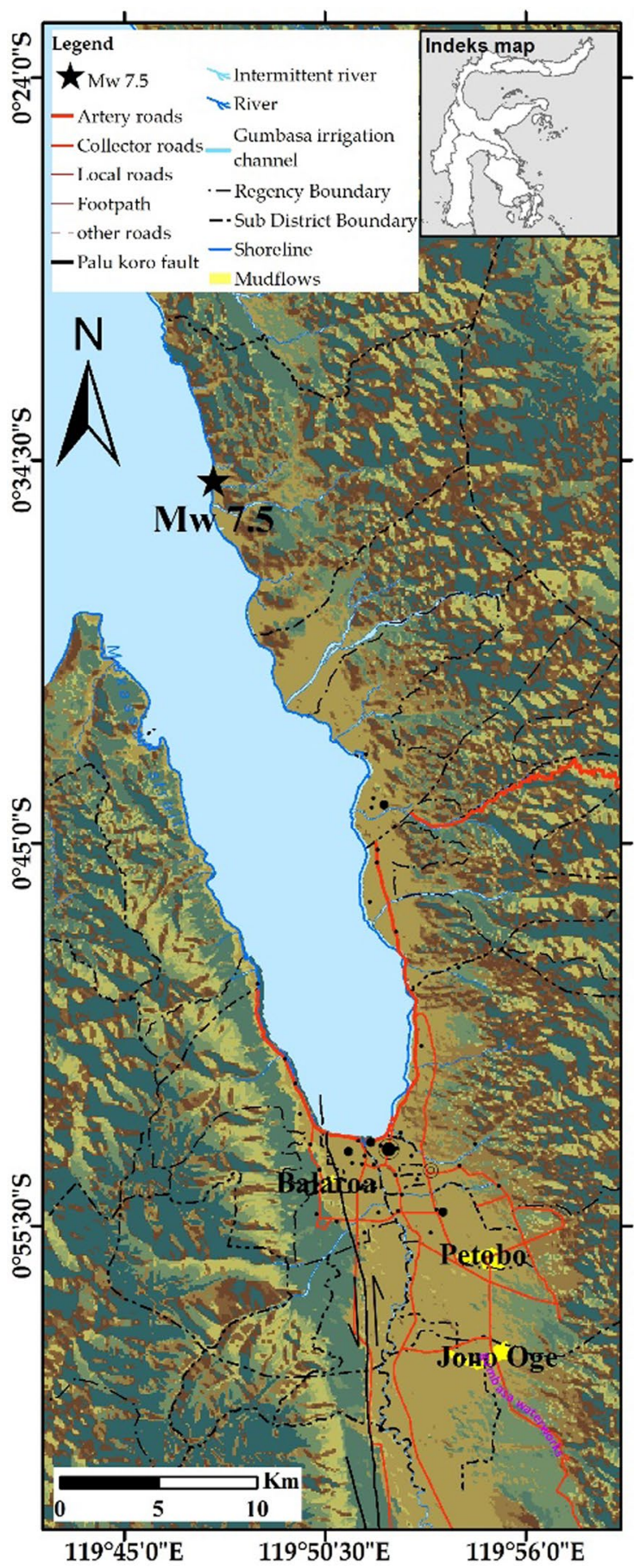

(a) Map of Palu CIty

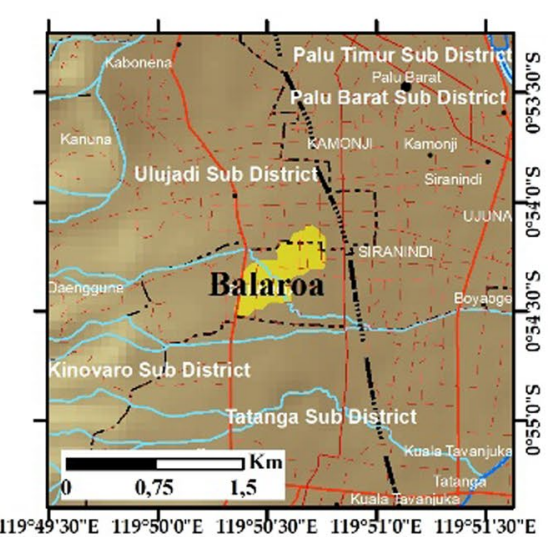

(b) Balaroa Mudflows

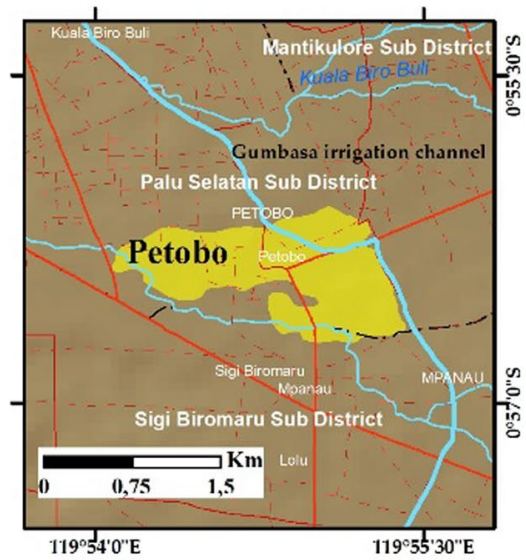

(c) Petobo Mudflows

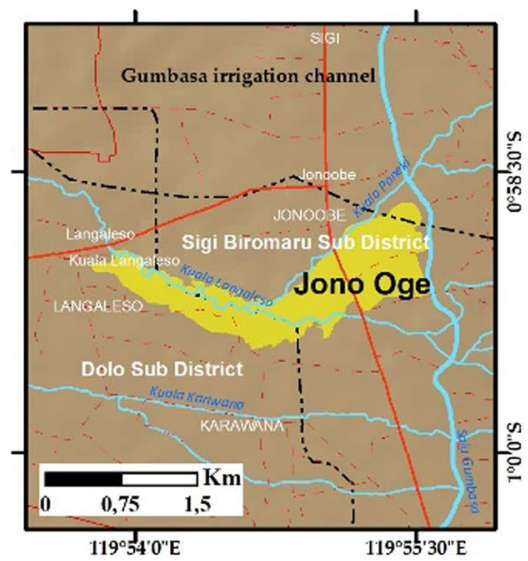

(d) Jono Oge Mudflows

Fig. 1 Liquefaction resulting mudflows in Palu City: a Map of Palu City, b Balaroa mudflows, c Petobo mudflows, and d Jono Oge mudflows

the city and coastal area caused enormous damages to the settlements and buildings (Sadly, 2018). This circumstance also developed liquefaction, landslide, and mudflows Mason et al. (2019). Thus, it is required to carry out liquefaction and mudflows research to identify and reduce the disaster risk.

The Palu City soil investigation report mentioned that the area was composed of alluvium deposits with a sand 


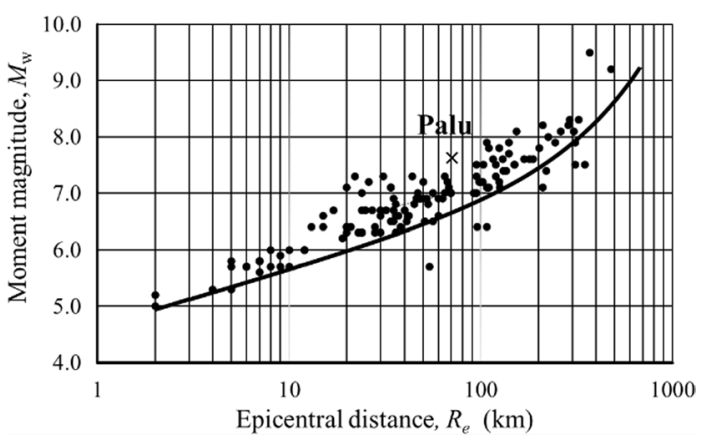

Fig. 2 The maximum epicenter distance to liquefaction sites, $R_{e}$ and the moment Magnitude, $M_{\mathrm{w}}$ (after Ambraseys 1988)

layer at the top, silt in the middle, and clay in the bottom (Widyaningrum 2012). Widyaningrum (2012) also conducted the semi-empirical and liquefaction potential index (LPI) methods with the results reported a shallow groundwater level in Palu City. Although this study provides valuable information regarding the liquefaction susceptibility in the Palu area, the researchers only used semi-empirical and geological procedures. Hence, the effect of liquefaction that causes mudflow was not explained in this study. In general, previous studies analyzed the liquefaction potential based on the semi-empirical approach proposed by Idriss and Boulanger (2008). The liquefaction potential index (LPI) was determined by referring to the (Iwasaki et al. 1981) methods. The National Center for Earthquake Study released a collateral hazard map due to the 2018 earthquake in Palu, which included flow liquefaction and mudflow Irsyam et al. (2019).

Some researches on liquefaction studies apply microtremor wave propagation. Futhermore, the researchers also made numerical models of geotechnical effects of differences in seismic parameters (Araujo and Ledezma 2020). This study was carried out by correlating the wave characteristics, soil site classification, and liquefaction evidence during the 2018 earthquake. The objective of this study is to evaluate the soil susceptibility of Palu City to the liquefaction phenomenon, which might cause flash floods that resulted in the massive mudflows and soil dynamic effect. In addition to this, to support the regional infrastructure planning and development. The soil susceptibility resulting from the dynamic effects was analyzed by combining the velocity amplification values obtained from microtremor measurements with the $S P T$ derived from the site classification by using an ArcGIS framework.

\section{Geological condition of Palu}

The geology of the Palu area is dominated by sedimentary and volcanic deposits from the Cretaceous and Paleogene (Fig. 3). Palu contains five formations: Formation of the

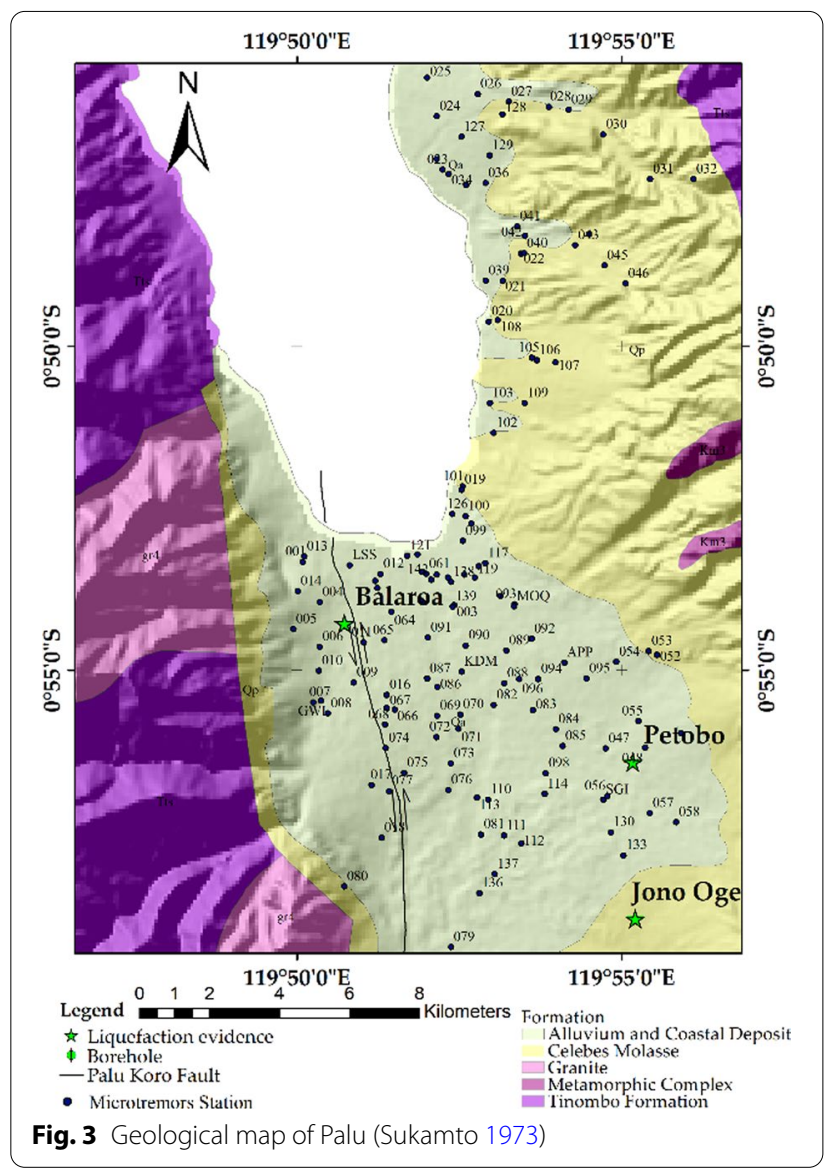

Alluvium and Coastal Deposits, Formation of the Celebes Molasse, Formation of Granite, Metamorphic Complex, and Formation of Tinombo. The Geological Survey of Indonesia investigated the formations in the 1970s by Sukamto (1973).

The Palu City area is a quarter sedimentary expanse. Silty clay, silt alluvial sand and old river channel deposits were found along the Palu river at the lower elevations near the valley's center. Young and old alluvium fan deposits are surficial sediments in the low relief hills, which extend on the west and east sides of the valley. Deposits of colluvium debris from gravel sand often occur at higher altitudes Thein et al. (2014).

Balaroa morphology is approximately the similar to Petobo, although Balaroa is located near the western hills where the slope is more considerate than Petobo. There is no irrigation channel in Balaroa, as opposed to another area affected by soil flow. The most likely factor that triggered significant liquefaction in the region is the influence of the colluvial fan topographic, which is controlled by natural shallow groundwater Faris et al. (2019). Petobo and Jono Oge are located on a gentle slope in the eastern 
hills. The morphology of the area is a colluvial deposition area originating from the hill.

\section{Research method}

\section{Horizontal to vertical spectrum ratio (HVSR) method}

Data resulted from the microtremor measurement was analyzed using the Horizontal to Vertical Spectral Ratio (HVSR) method. Subsequently, a comparison was carried out between $H$ (horizontal) and $V$ (vertical) spectrum data. The HVSR method was introduced by Nakamura (1989), to estimate the resonance frequency and local sediment amplification factor of microtremor data. Moreover, it is adopted to estimate the soil susceptibility index (Nakamura 1997) and the building susceptibility index (Sato et al. 2008). The critical parameters generated from the HVSR method are the resonance frequency and amplification factor. The HVSR method carried out for sediment data measurements should meet the criteria recommended by SESAME (2004).

The dominant frequency and amplification factor of the site can be determined by using the $H / V$ ratio. Nakamura (1997) also proposed the ground shear strain (GSS) to be used as a mechanism to determine the level of liquefaction by comparing the value of ground shear strain (GSS) and seismic susceptibility index $\left(K_{g}\right)$ to determine the location of the soil movement in the 2018 liquefaction. The value of GSS and $K_{g}$ can be used to determine the location of vulnerable liquefaction points. A point with a higher $K_{g}$ value indicates higher liquefaction potential. The GSS values are determined from the soil structure strains, which can be defined as.

$$
\gamma=K_{g} \alpha
$$

where $\gamma=$ ground shear strain, $\alpha=$ peak ground acceleration at bedrock. The value of $K_{g}$ can be used to verify the predicted liquefaction points by comparing them to the damage resulted from the 2018 earthquake. The $K_{g}$ value is obtained by squaring the $H V S R$ spectrum with the peak value of the resonant frequency, which is determined by Nakamura (2000) as:

$$
K_{g}=\frac{A_{g}^{2}}{f_{g}}
$$

where $K_{g}=$ the seismic susceptibility index, $A_{\mathrm{g}}=$ amplification factor of the $H V S R$ spectral peaks, and $f_{\mathrm{g}}=$ natural frequency of the ground surface $(\mathrm{Hz})$.

In this study, the evidence of Balaroa liquefaction events was compared by applying the (Idriss and Boulanger 2008) method, which is more suitable for comparing the theory and field results of the liquefaction events. Many researchers have widely used this method, such as Mase et al. (2020), Jalil et al. (2020). The safety factor against liquefaction is determined by comparing the cyclic resistance ratio $(C R R)$ and cyclic stress ratio $(C S R)$, which is expressed as:

$$
F S_{l i q}=\frac{C R R_{M, \sigma^{\prime} v c}}{C S R_{M, \sigma^{\prime} v c}}
$$

where $F S_{\text {liq }}=$ the safety factor against liquefaction. The values were predicted based on the N-SPT penetration resistance measured in various depths.

\section{Field investigation}

This paper uses the results of a microtremor survey in 150 measurement stations carried out by Thien (2015). The measuring instruments include the PIC, Portable Intelligent Collector, microtremor measurement device with three sensor components, and a data recording unit. Microtremor was repeatedly recorded in $40.96 \mathrm{~s}(4,096$ data in $100 \mathrm{~Hz}$ sampling) at each measured location, and 10.24 s of data were selected from the viewpoint of less artificial noise (Sato et al. 2008). Then the selected data was transformed into Fourier before the horizontal to vertical spectrum ratio was calculated for each component of each measurement. Finally, the $H / V$ spectrum ratio was derived as the average spectrum ratio (Nakamura, 1989). The dominant frequency and amplification factor were obtained from the $H / V$ spectral ratio. This procedure was performed in 1990. The data microtremor survey is presented in Fig. 3, and the seven boreholes (BH) used for the analysis are shown in Fig. 4 which are located in the Balaroa village and Palu coastal area. The boreholes $\mathrm{BH}-1$ and $\mathrm{BH}-2$ were at a depth of $20 \mathrm{~m}$, and $\mathrm{BH}-3$ to $\mathrm{BH}-7$ were at a depth of $30 \mathrm{~m}$ below the ground surface.

Figure 5 shows the ground slope plan-view from Balaroa village to the coastal area. The loose sand layer was found on the surface between 1 and $15 \mathrm{~m}$ depth below the ground surface, whereas a relatively rigid layer was found in the borehole BH-7. At a depth of 15 and $25 \mathrm{~m}$, the silty gravel layer was found with an N-SPT value of 50 . The average $N-S P T$ value was higher than 50 at a depth of 25 and $30 \mathrm{~m}$, indicating a dense layer. The dominant sedimentary soil that stretches in the Palu basin consists of gravely sand, sandy silt, sand, silt, sand and gravel, and silty gravel.

The groundwater level (GWL) in the command area was between 0.3 and $10 \mathrm{~m}$ below the ground surface. Near the coast of Palu City, the groundwater level was found at a depth of $0.3 \mathrm{~m}$. While in the hills on the west of Balaroa, the groundwater was found at a depth of $10 \mathrm{~m}$ (Fig. 5). The boreholes $\mathrm{BH}-1$ and $\mathrm{BH}-2$ were located near the coastal area of Palu City, and BH-3 to BH-7 were on Balaroa gentle slope. A higher $S P T$ value was found in $\mathrm{BH}-7$ and $\mathrm{BH}-2$, which were located on Balaroa steep 


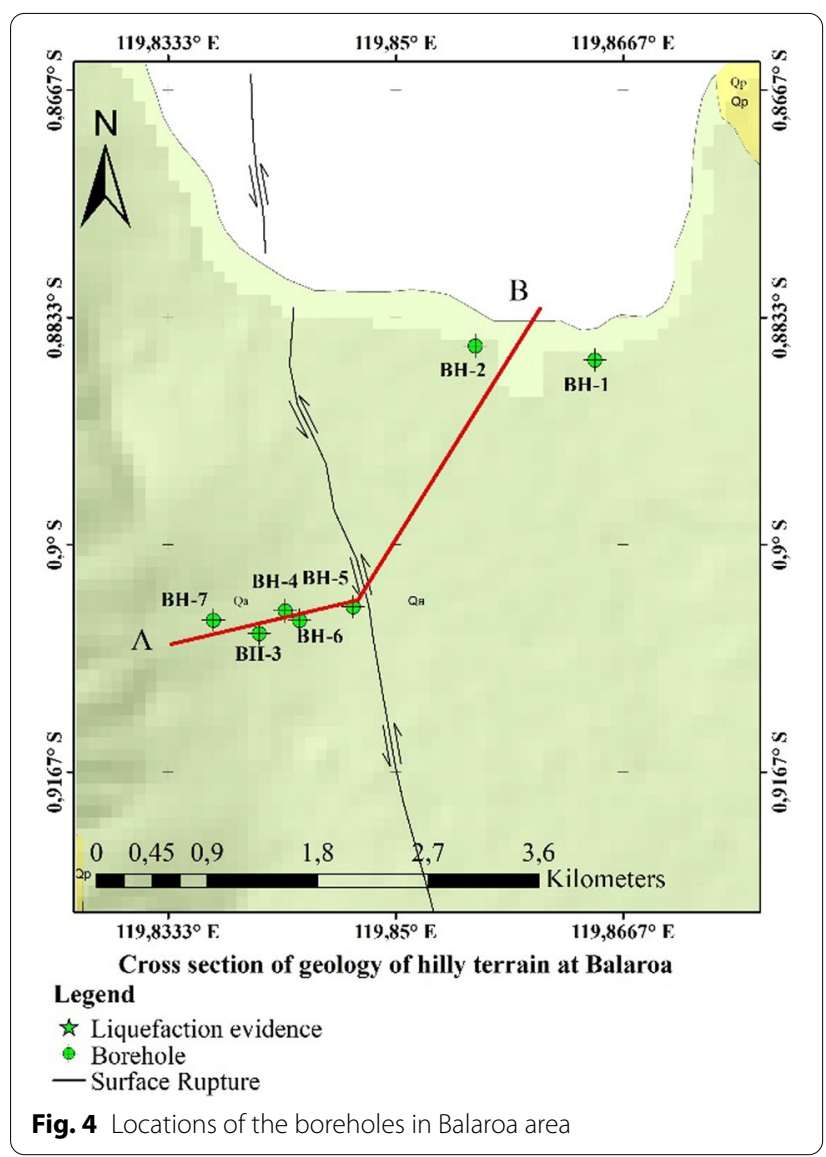

slope and near the coastal area, respectively. The soil resistance of $\mathrm{BH}-3, \mathrm{BH}-4, \mathrm{BH}-5$, and $\mathrm{BH}-6$ was relatively weak in comparison to $\mathrm{BH}-7$ and $\mathrm{BH}-2$. The variation of $\left(N_{1}\right)_{60}$ values is, as shown in Fig. 5.

The groundwater level in the Palu coast and Balaroa gentle slope was $0.3 \mathrm{~m}$ and at a depth of $10 \mathrm{~m}$, respectively. The groundwater level in the Palu basin was shallow, with a deposit soil layer containing loose sandy soil, a confined aquifer, and low-level permeability (JICA 2019).

\section{Flow liquefaction analysis}

The flow liquefaction phenomenon may take place in either saturated loose sands, silts, or very sensitive clays as it is associated with the contractive behavior of loose sand materials to become liquefaction which possibly occurs during a strong earthquake (JICA, 2019). Li and Ming (2000) carried out a performance model to explain the liquefaction loading conditions. The simulations for undrained triaxial compression were established from anisotropic stress conditions. Laboratory test data and models which calculate the flow liquefaction and cyclic mobility illustrate the behavior of saturated loose sand, dense sand, and undrained soils during the shear loading (monotonic and repetitive), as have been published by several researchers (Robertson, 2010). Furthermore, by using $S P T$ penetration resistance data, flow liquefaction can be predicted.

The corrected $S P T$ blow counts $\left(N_{1}\right)_{60}$ shown in Fig. 5 is employed to predict flow liquefaction. The procedure to evaluate the contractive state susceptibility of the soil to flow liquefaction based on the relationship between yield strength ratio and penetration resistance was proposed by Olson and Stark (2003). The yield strength ratio in Fig. 9 presents the penetration resistance $\left(N_{1}\right)_{60}$ value that is limited to be less than 12 (Eq. 4). The boundary of the relationship between yield strength ratio and penetration resistance are described as:

$$
\frac{S_{u}(\text { yield })}{\sigma_{\nu 0}^{\prime}}=0.205+0.0075\left[\left(N_{1}\right)_{60} \pm 0.04\right]
$$

$$
\text { for }\left(N_{1}\right)_{60} \leq 12
$$

where $\frac{s_{u}(\text { yield })}{\sigma_{v 0}^{\prime}}$ is yield strength ratio, $\left(N_{1}\right)_{60}$ is penetration resistance.

The liquefaction susceptibility to flow is highly dependent on the initial state of the soil. Fear and Robertson (1995) proposed a susceptibility boundary relationship employing the concept of a critical state soil mechanics and laboratory test results. Fear and Robertson (1995) recommended the boundary for practices that describe whether a field is susceptible to a flow failure based on the compatibility to the theory, laboratory test results, and field case history. This relationship is shown in Fig. 10. The recommended boundary relations can be expressed below:

$$
\left(\sigma_{v 0}^{\prime}\right)_{\text {boundary }}=9.58 \times 10^{-4}\left[\left(N_{1}\right)_{60}\right]^{4.79}
$$

\section{Flash flood caused mudflows}

Rapid landmass movement on gentle slopes is influenced by excess pore water pressure when the earthquake shocks trigger the water pressure in the aquifer to emerge to the ground surface. The generation of pore water pressures on loss soil shear strength has changed into the debris flow wave on the ground surface. Because there are no data available to reveal the peak runoff during the earthquake, this phenomenon is assumed to be a hypothesis similar to flash floods due to high rainfall events in the river basins. Rainfall-induced landslides are one of the disasters in complex areas of terrain, especially regions with heavy rainfall regularly. Landslides can occur in a catchment area of unconsolidated soil prone to landslides, as well as flash floods that occur caused by the catchment area broken watersheds. The landslides that occurred in Balaroa, Petobo, and Jono 


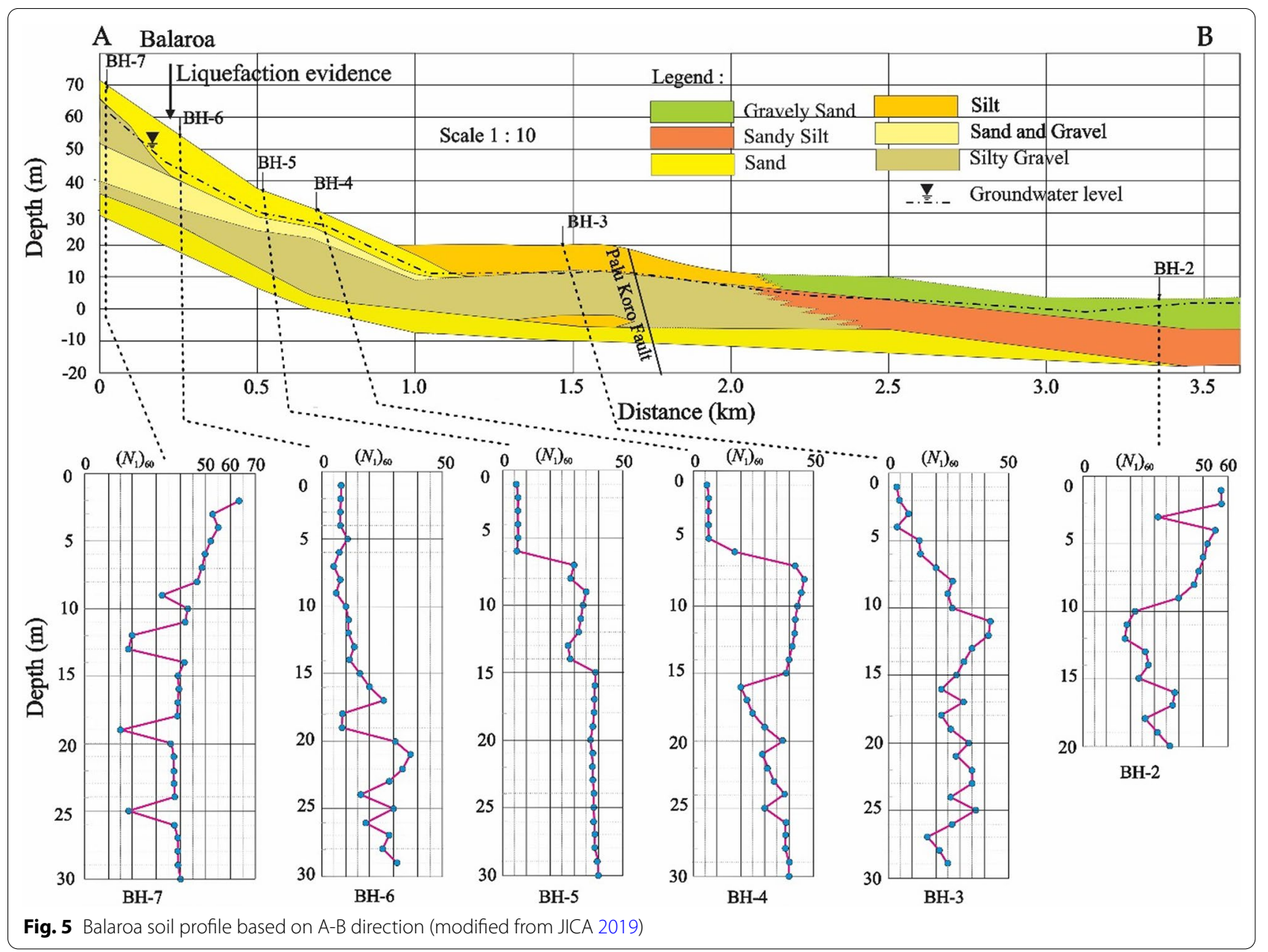

Oge were caused by a broken catchment area after the Palu earthquake.

The gentle slope had fissures/cracks in the catchment area of Balaroa, Petobo, and Jono Oge by $0.4 \mathrm{~km}^{2}, 1.43$ $\mathrm{km}^{2}$, and $1.35 \mathrm{~km}^{2}$, respectively (Mason et al. 2019). It is clear that flash flood is the primary cause of infrastructure and casualties during earthquakes in gentle slopes. Rainfalls flow from the catchment area into low-level slope areas. The surface runoff is referred to hydrograph unit and used to design the drainage system. The empirical methods were performed to represent the complex relationship between rainfall and peak surface runoff. The rational methods were conducted to analyze the runoff in a relatively small catchment area. The runoff is expressed as:

$$
Q=K i A
$$

where $Q=$ the maximum runoff in $\left(\mathrm{cm}^{3} / \mathrm{s}\right), i=$ the designed mean intensity of rainfall $(\mathrm{m} / \mathrm{s}), A=$ area of catchment $\left(\mathrm{m}^{2}\right), K=$ surface runoff coefficient, for slope $K$ is 1 (Geotechnical Control Office 1984).

Equation 6 is generally used to calculate the runoff, thus the water spray from the aquifer layer can be assume as a runoff. Furthermore, $i$ is the mean intensity of rainfall, which is assume to the velocity of water flowing on the sand as proposed by Darcy's law as follows:

$$
v=\frac{\Delta h}{l}
$$

By applying the Darcy equation, Eq. (6) becomes

$$
Q=K v A
$$

where $K=$ coefficient of surface runoff, $\mathrm{v}=$ velocity $(\mathrm{m} /$ $\mathrm{sec}), \Delta h=$ different in height $(\mathrm{cm}), k=$ coefficient of permeability $(\mathrm{cm} / \mathrm{s}), l=$ distance $(\mathrm{cm})$. 


\section{Results and discussion}

\section{Ground shear strain (GSS) and soil deformation}

The value of the ground shear strain is the parameter used to represent the soil strain in the event of earthquake. The higher the soil shear strain value, the more likely the surface sediment layer can stretch. These strains and shifts will cause deformations, such as soil fractures, landslides, and liquefaction (Nakamura, 1989). Conversely, the smaller the GSS value, the lesser soil layer deformation is likely to occur. Ground shearstrain at the surface can be obtained by using Eq. 1 . The PGA values at the bedrock are within the range 100550 gals (Thein et al. 2014).

Figure 6 shows the distribution of ground shearstrain values depicted on the command area's Digital Elevation Model (DEM) map. The sufficient value of the shear strain was almost the same as the distribution of the $K g$ value, where the moderate to high value was found in the Palu valley area and was directed by the Palu Koro fault line. Soil layers will experience plastic conditions if the ground shear strain (GSS) values range from $1000 \times 10^{-6}$, and the ground shear strain (GSS) values range higher than $10,000 \times 10^{-6}$ (Ishihara, 1996).

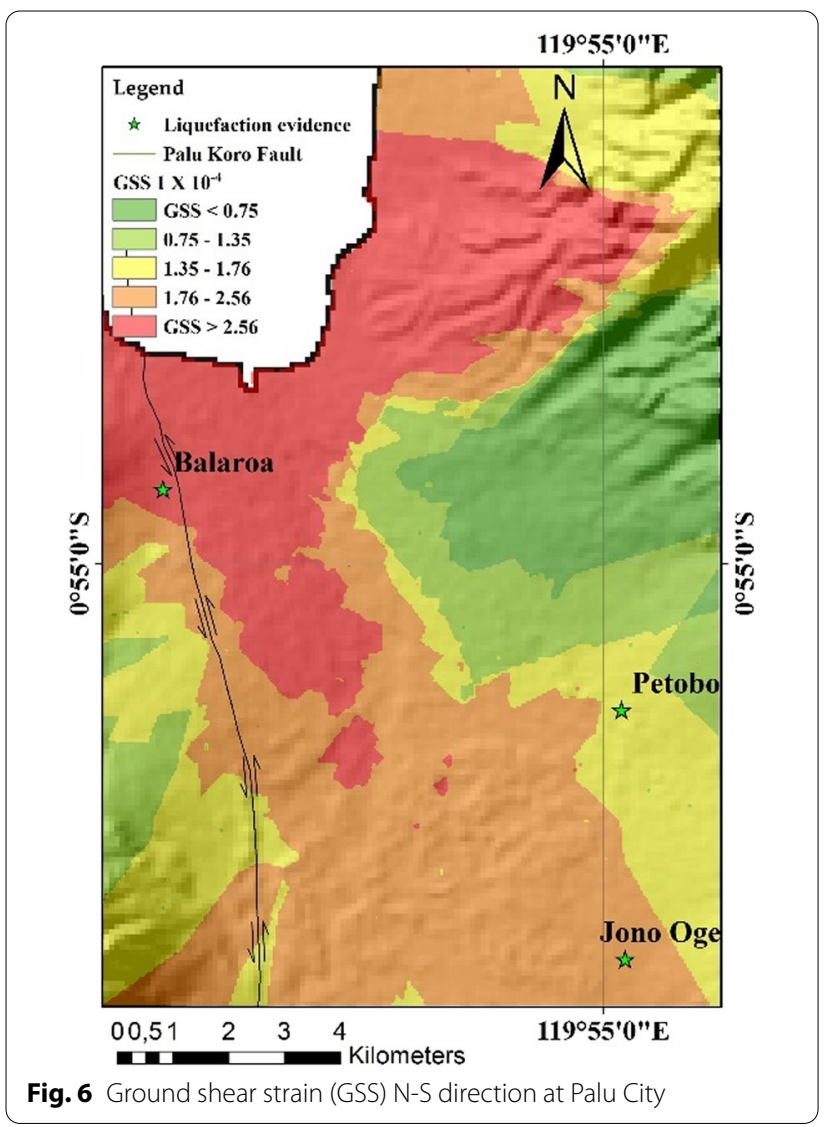

Such soil condition is vulnerable to landslide and liquefaction whenever an earthquake occurs.

The values of GSS show shallow sedimentary layers in Palu City, as presented in Fig. 6. The magnitude of GSS values ranged from $0.75 \times 10^{-4}$ to $2.56 \times 10^{-4}$. Thus by having such a range, the soil began to be elastic-plastic that the soil was easy to experience fractures and surface soil settlement which is shown in Table 1 (Ishihara, 1996). In addition, high ground shear strain values were found in the southern, eastern, and western parts of Palu City surrounding Balaroa and following the trail of the Palu Koro fault. These results tend to be similar to GSS (BMKG, 2018). These findings in Balaroa are in line with the 2018 Palu earthquake geotechnical damage facts, especially in soil displacement caused by fault movements resulting in liquefaction and mudflows. Miyajima et al. (2019) also discovered that those fault movements induced large soil displacement in Palu City.

Equation 2 is used to determine the value of the seismic susceptibility index $\left(K_{g}\right)$. The Seismic susceptibility index is also related to geomorphological condition resonant frequency (see Fig. 7). A high value of seismic susceptibility indicates that the area consisted of alluvial material similar to the coastal area. Areas with a high seismic susceptibility index $\left(K_{g}\right)$ were found in the valley and coastal sediment areas. In hilly areas, it indicates a shallow seismic susceptibility index.

\section{The liquefaction analysis under the empirical methods}

The evaluation method of liquefaction using the N-SPT data is called the simplified procedure. It is a deterministic method using a seismic load by considering the cyclic stress ratio $(C S R)$. The ability of the soil layer to resist liquefaction is expressed in the cyclic resistance ratio (CRR ). Liquefaction resistance of granular soils is also determined by using the $C R R$ of the liquefaction potential assessment under the simplified shear stress technique (Idriss and Boulanger 2008).

Based on the geological characteristics, the investigation of the subsurface soil layer in the Balaroa areas shows that it was dominated by granular material. Sandy silt, silt and gravel, and dominant silt sand found in the

Table 1 Ground shear strain dependence of dynamic soil properties (Ishihara 1996)

\begin{tabular}{|c|c|c|c|}
\hline Size of GSS & $10^{-6} \ldots 10^{-5}$ & $10^{-4} \ldots 10^{-3}$ & $10^{-2} \ldots 10^{-1}$ \\
\hline Phenomena & Wave, vibration & Crack, Settlement & $\begin{array}{c}\text { Landslide, Soil } \\
\text { Compaction, } \\
\text { Liquefaction }\end{array}$ \\
\hline $\begin{array}{l}\text { Dynamic proper- } \\
\text { ties }\end{array}$ & Elasticity & Elasto-plasticity & Collapse \\
\hline
\end{tabular}




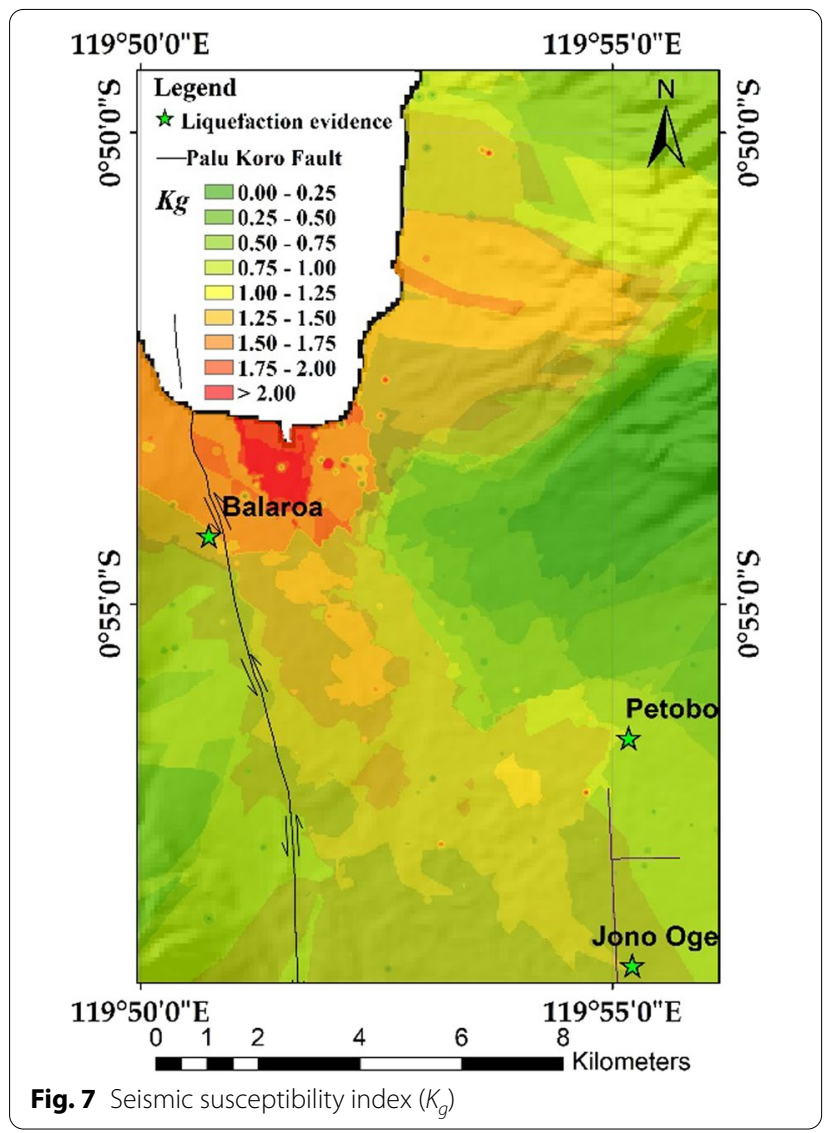

first $20 \mathrm{~m}$ depth were with FC (fines content) in the range of $15-40 \%$. This soil layer was followed by silt and sand in the $30 \mathrm{~m}$ depth, with FC ranging from 5 to $45 \%$.

The soil classification was determined based on the average $N-S P T$ of the top $30 \mathrm{~m}$ of the soil column. The procedure for calculating the average $N-S P T$ follows the Indonesian Standards (SNI 03-1726-2019 2019). It indicates that soil in Balaroa consists of medium soil (SD) and soft soil (SE) classifications. The characteristics of medium soil site (SD) class with $N-S P T$ values 15 to 50 were found at $\mathrm{BH}-1, \mathrm{BH}-2, \mathrm{BH}-4$, and $\mathrm{BH}-5$ to $\mathrm{BH}-7$ locations. Meanwhile, the soft soil site class (SE) characteristics with $N-S P T$ value $\leq 15$ were found at $\mathrm{BH}-3$ and $\mathrm{BH}-6$ locations.

The peak ground acceleration (PGA) on each borehole was determined based on the Indonesian National Standard or SNI 03-1726-2019. PGA was calculated by observing the specific site and considering the amplification factor, including the site coefficient $\left(F_{P G A}\right)$ value. The maximum ground acceleration at the surface $\left(P G A_{M}\right)$ is shown in Table 2.

The maximum PGA value was found in BH-1, which was located close to the coast, while the minimum $P G A$ value was in the hilly area of $\mathrm{BH}-7$. The areas near the
Table 2 The value of $P G A_{M}$ on each borehole

\begin{tabular}{lllll}
\hline Borehole & GWL $(\mathbf{m})$ & PGA $(\mathbf{g})$ & $\boldsymbol{F}_{\boldsymbol{P G A}}$ & $\boldsymbol{P G A}_{\boldsymbol{M}}(\mathbf{g})$ \\
\hline $\mathrm{BH}-1$ & 0.8 & 0.823 & 1 & 0.823 \\
$\mathrm{BH}-2$ & 0.3 & 0.797 & 1 & 0.797 \\
$\mathrm{BH}-3$ & 3.2 & 0.732 & 1 & 0.732 \\
$\mathrm{BH}-4$ & 2.1 & 0.738 & 1 & 0.738 \\
$\mathrm{BH}-5$ & 0.55 & 0.755 & 1 & 0.755 \\
$\mathrm{BH}-6$ & 6.0 & 0.742 & 1 & 0.742 \\
$\mathrm{BH}-7$ & 10.0 & 0.722 & 1 & 0.722 \\
\hline
\end{tabular}

coast indicated extreme ground motion due to its maximum soil density, which was stable against landslides. The gentle slope of the Balaroa hilly indicated maximum ground motion, in addition to the loose sand layer that enabled liquefaction to occur. The results of semi-empirical analyses are as shown in the liquefaction potential in Fig. 8. The analysis results prove that the liquefaction that occurred in 2018 could be predictable by using the microtremor seismic susceptibility index data $\left(K_{g}\right)$.

The soil density parameters used in the analysis were the dry and wet soil unit weight of $17.0 \mathrm{kN} / \mathrm{m}^{3}$ and 19.5 $\mathrm{kN} / \mathrm{m}^{3}$. The groundwater level influenced the calculation of total stress and not the effective vertical stress. The depth of the groundwater level is presented in Table 2 . The results of the potential liquefaction calculation in BH-6 are presented in Fig. 8.

Figure 8 shows that the depth of liquefaction was less than $16 \mathrm{~m}$ below the ground surface. The findings from the N-SPT and microtremor seismic susceptibility index data indicate a significant factor of the deposited soil layer on the response susceptibility and manifestation of liquefaction damage. These locations experienced the liquefaction during the 2018 earthquake. The analysis of the potential liquefaction of all boreholes is shown on Table 3.

\section{Flow liquefaction}

The penetration resistance plotted in Fig. 9 are the values of $\left(N_{1}\right)_{60}$ which are limited to less than 12 based on the data in Fig. 5. The value of yield strength ratio, as shown on Table 4, is generally referred to as residual strength and the denoted, $S_{u}$.

A study by Ishihara (2019) showed that the calculation failure of the liquefaction flow was the back-calculation of the residual strength ratio based on the actual case of slide flow occurring in the Palu plains after the 2018 earthquake. The resulted $S_{u}$ values for Palu mainland ranges within $0.05-0.25$ which are in accordance with the range values of residual strength ratio of $0.240-0.272$ as shown on Table 4. 

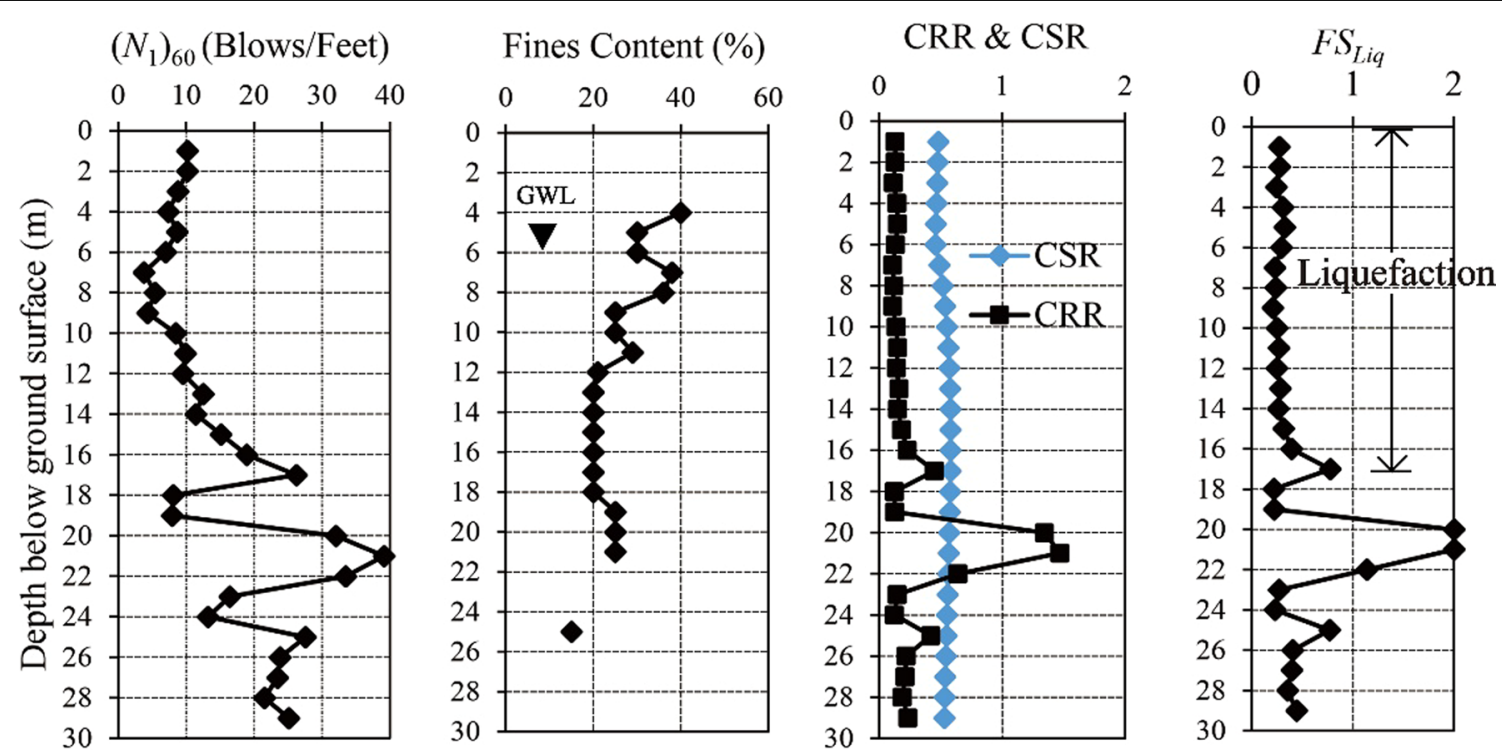

Fig. 8 The example curve of $F S_{\text {liq, }} C R R$, and $C S R$ at $B H-6$

Table 3 Liquefaction Potential in each borehole

\begin{tabular}{lll}
\hline Borehole & Safety factor & Liquefaction potential \\
\hline $\mathrm{BH}-1$ & $F S_{\text {Liq }}>1$ & No liquefaction \\
$\mathrm{BH}-2$ & $F S_{\text {Liq }}>1$ & No liquefaction \\
$\mathrm{BH}-3$ & $F S_{\text {Liq }}<1$ & Liquefaction \\
$\mathrm{BH}-4$ & $F S_{\text {Liq }}<1$ & Liquefaction \\
$\mathrm{BH}-5$ & $F S_{\text {Liq }}<1$ & Liquefaction \\
$\mathrm{BH}-6$ & $F S_{\text {Liq }}<1$ & Liquefaction \\
$\mathrm{BH}-7$ & $F S_{\text {Liq }}>1$ & No liquefaction \\
\hline
\end{tabular}

The nature of loose sand soil fabric with flow behavior can be evaluated based on the penetration resistance data (Fear and Robertson 1995). Olson and Stark (2003) conducted a static stability analysis to predict the migration of the soil particle with residual strength due to an earthquake. The SPT data based on the flow failure susceptibility relationships taken from the case history data proposed by (Fear and Robertson, 1995) was used to carry out the susceptibility analysis of flow liquefaction. The susceptibility flow liquefaction in the soil layer is identified by the soil contractive state (Fig. 10). The evaluation of liquefaction based on data $\left(N_{1}\right)_{60}$ and the vertical effective stress is plotted in Fig. 10. These plots show the layers of contractive soil and identify the flow failure. The plotting results, as shown in Table 5 , indicate that the region experiences flow failure, which is consistent with the 2018 liquefaction occurring in Palu City.

In addition, Robertson et al. (2019) also reported that based on the field monitoring, flow liquefaction taking

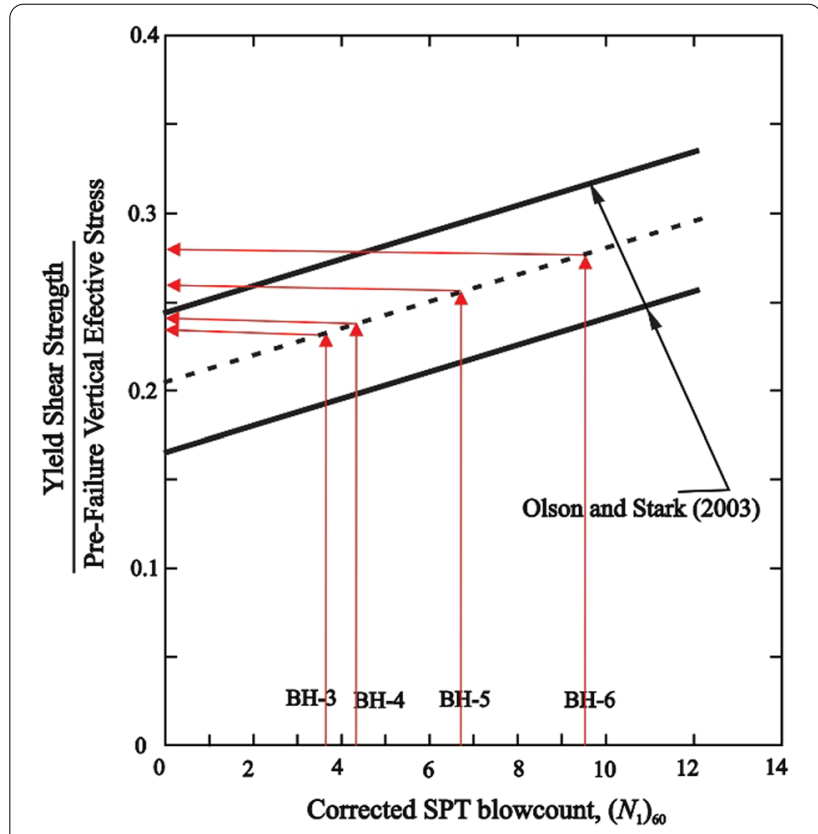

Fig. 9 The corrected SPT blow count relationship to estimate liquefied strength ratios and for liquefaction flow failures, as proposed by Olson and Stark (2003). Red arrows indicate the BH-3, BH-4, BH-5, and $\mathrm{BH}-6$ estimation

place in the Balaroa, Petobo, and Jono Oge areas at the slope ground levels were $3.4 \%, 2 \%$, and $1.4 \%$ respectively. Such softening soil moved to a distance up to $1000 \mathrm{~m}$, $2200 \mathrm{~m}$, and $3900 \mathrm{~m}$ for the area of Balaroa, Petobo, and Jono Oge, respectively. The soil movement was a distant 
Table 4 Yield strength ratio and $\left(N_{1}\right)_{60}$ value from Fig. 9

\begin{tabular}{llll}
\hline Borehole & $\left(\boldsymbol{N}_{1}\right)_{60}$ & $\frac{s_{u}(\text { yield })}{\sigma_{v 0}^{\prime}}$ & Liquefaction potential \\
\hline $\mathrm{BH}-1$ & $>12$ & - & No liquefaction \\
$\mathrm{BH}-2$ & $>12$ & - & No liquefaction \\
$\mathrm{BH}-3$ & 3.91 & 0.240 & Flow liquefaction \\
$\mathrm{BH}-4$ & 4.21 & 0.245 & Flow liquefaction \\
$\mathrm{BH}-5$ & 6.43 & 0.260 & Flow liquefaction \\
$\mathrm{BH}-6$ & 9.55 & 0.272 & Flow liquefaction \\
$\mathrm{BH}-7$ & $>12$ & - & No liquefaction \\
\hline
\end{tabular}

Table 5 Flow liquefaction susceptibility in each borehole

\begin{tabular}{lllcl}
\hline Borehole & Depth $(\mathbf{m})$ & $\left(\boldsymbol{N}_{\mathbf{1}}\right)_{\mathbf{6 0}}$ & $\boldsymbol{\sigma}_{\mathbf{v} \mathbf{0}}^{\prime}\left(\mathbf{k N} / \mathbf{m}^{\mathbf{2}}\right)$ & Liquefaction potential \\
\hline $\mathrm{BH}-1$ & 1 & 28.90 & 15.54 & Dilative \\
$\mathrm{BH}-2$ & 1 & $>50$ & 11.88 & Dilative \\
$\mathrm{BH}-3$ & 4 & 3.91 & 62.15 & Contractive \\
$\mathrm{BH}-4$ & 4 & 4.21 & 54.11 & Contractive \\
$\mathrm{BH}-5$ & 6 & 6.43 & 62.16 & Contractive \\
$\mathrm{BH}-6$ & 12 & 9.55 & 160.14 & Contractive \\
$\mathrm{BH}-7$ & 1 & $>50$ & 17.00 & Dilative \\
\hline
\end{tabular}

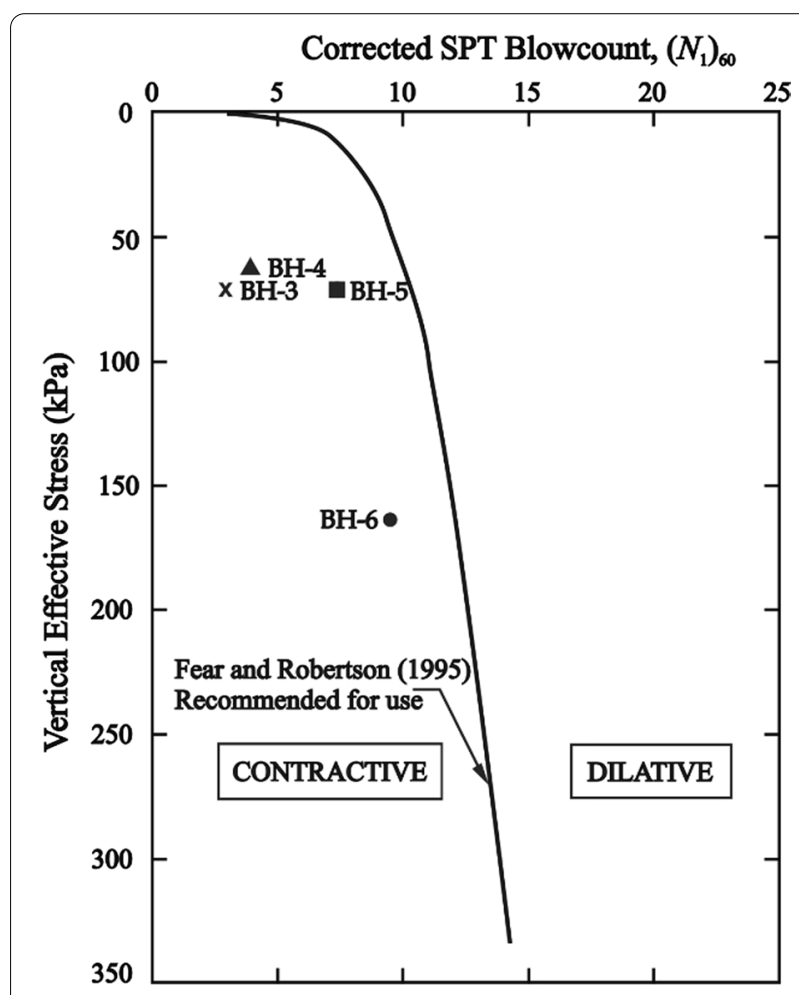

Fig. 10 Separating relationships between contractive and dilative conditions by using the flow failure case histories and corrected SPT blowcount (Fear and Robertson 1995)

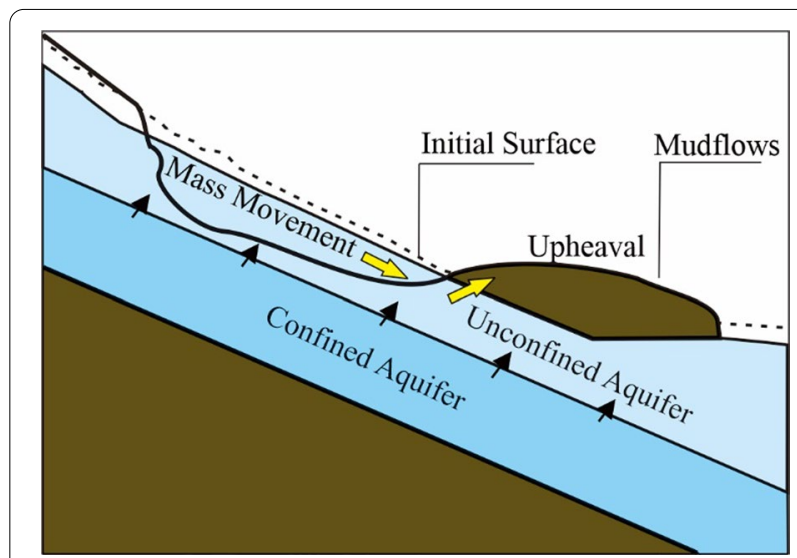

Fig. 11 The illustration earthquake induced flow liquefaction in Balaroa

trajectory that buried thousands of houses and other facilities in Balaroa, Petobo, and Jono Oge.

\section{A phenomena of flashflood like: the caused mudflows}

Flow liquefaction occurrence in Palu City was similar to flash flood, which considers as rapid flooding of water above the ground caused by a sudden burst of water from an aquifer strip, or the release of retained water (e.g., the rupture of an impermeable confined aquifer). Flow liquefaction or flash flood occurs for a short period, usually within a few minutes to a few hours, distinguishing it from fluvial flooding. The phenomenon of liquefaction in Palu City showed similar behavior to the flash floods event.

The uniqueness of the geological system in the region of Palu determines its hydro-morphological state, including the groundwater basin. On these sediment layers lie Petobo, Balaroa, and Jono Oge that suffered a wide degree of liquefaction-induced-flow failure. This aquifer layer is the Palu groundwater basin, which has a very high average aquifer transmissivity value. The landslide event within the earthquake in Balaroa is illustrated in (Fig. 11).

The groundwater level in the Petobo area was shallow and was affected by the infiltration of the Gumbasa irrigation channel (Fig. 12). The soil layer was very saturated in addition to the presence of a confined aquifer layer. The water flow in the channel enters the porous soil layer through the tear gap resulted from the earthquake shocks. In this condition, the soil turned into pulp and was carried away by the flash flood waves. The soil types in Petobo and Jono Oge are shown in Fig. 13a, b, respectively. The soil layer was permeable and porous so that the sub-surface water pressed out through the gaps and raised the sediment by approximately $5 \mathrm{~m}$ (JICA 2019). Such rapid change of stress in the soil made the effective 


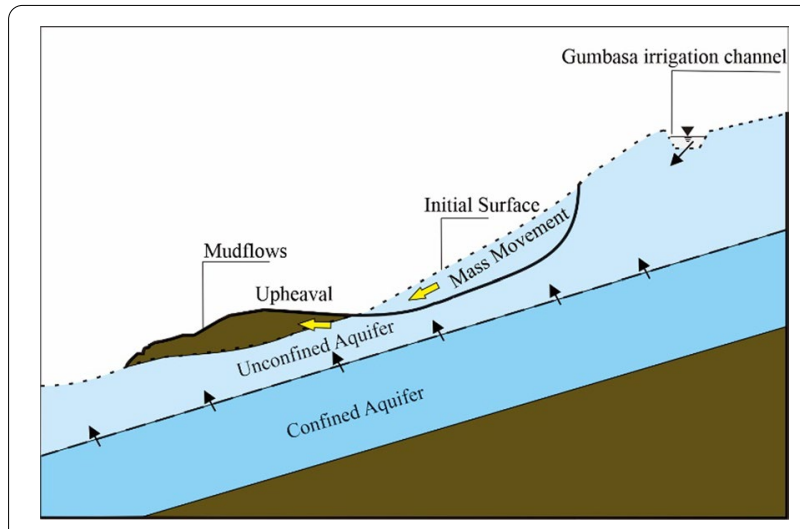

Fig. 12 The ilustration of mudflows induced by earthquake in Petobo and Jono Oge

vertical soil stress become zero and reached the maximum pore water pressure. Thus, the soil layer induced enormous strain and liquify.

The movement of soil masses and rock debris down a slope or the rapid and gradual sinking of the ground surface in a dominant vertical direction are in response to the gravitational force. Ground movement velocity significantly affects the volume of the landmass on the downslope. Soil mass movement velocity strongly depends on groundwater level fluctuation, dynamic viscosity coefficient, and sliding surface mass engineering properties Naing et al. (2018). Considering the impacts and damages caused by the mass movement, it is essential to predict its runout distance, velocity, moving volume, and coverage area Fathani et al. (2017). The mass movement model was introduced by several researchers Fathani et al. (2017), Syah et al. (2019). Small earthquakes of $M_{\mathrm{w}} 4$ can produce landslides, whereas the event

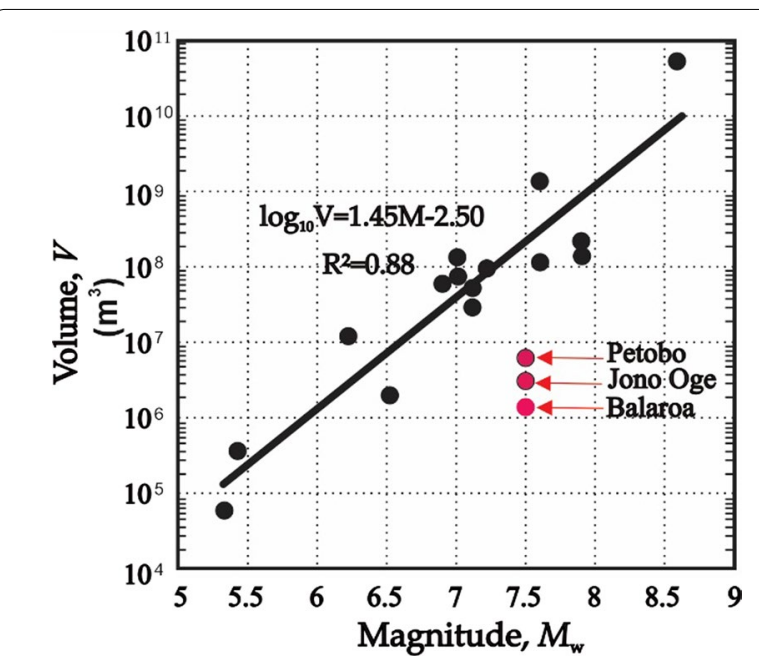

Fig. 14 Earthquake magnitude versus total volume of material in landslides triggered by earthquake (modified Keefer 1994)

$M_{\mathrm{w}}>7.5$ usually creates a landslide of thousands of landslides on vulnerable slopes in an area of hundred square kilometers with millions of cubic volumes of loose material (Keefer, 1994). Keefer (1994) proposed a relationship between the magnitude of earthquakes and the historical number of landslides (Fig. 14). If Fig. 14 is applied for the $M_{\mathrm{w}} 7.5$ landslide in Palu City, it is found that the volume of landslide material is $2.3 \times 108 \mathrm{~m}^{3}$, which is considered as an enormous volume of landslides that buried and swept away residential areas in Palu City. However, the volume of the landslide triggered by $M_{\mathrm{w}} 7.5$ Palu earthquake on September 28, 2018, was estimated at $9.5 \times 10^{6}$ $\mathrm{m}^{3}$, distributed in Balaroa, Petobo, and Jono Oge equivalent with $3 \mathrm{~m}$ in the height of debris.

By applying Eqs. (6), (7), and (8), the results of the flash flood discharge and velocity can be obtained, as shown

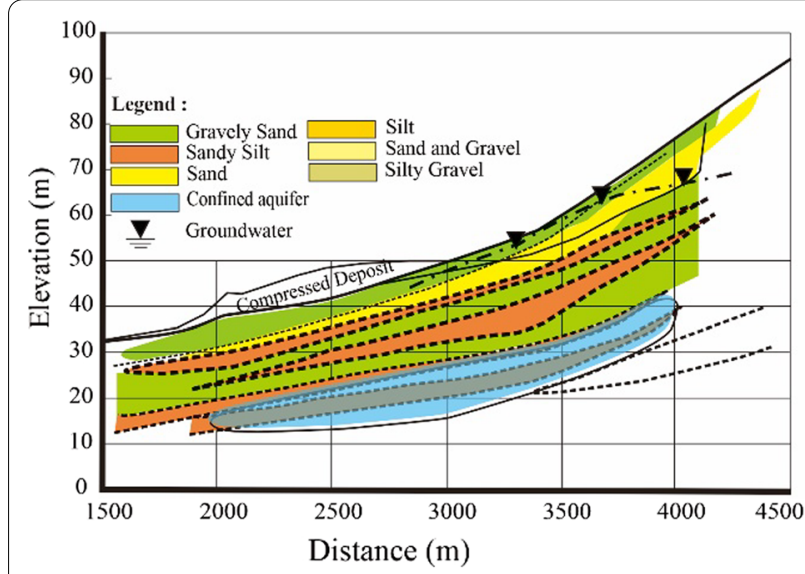

(a) cross-section in area mudflows of Petobo

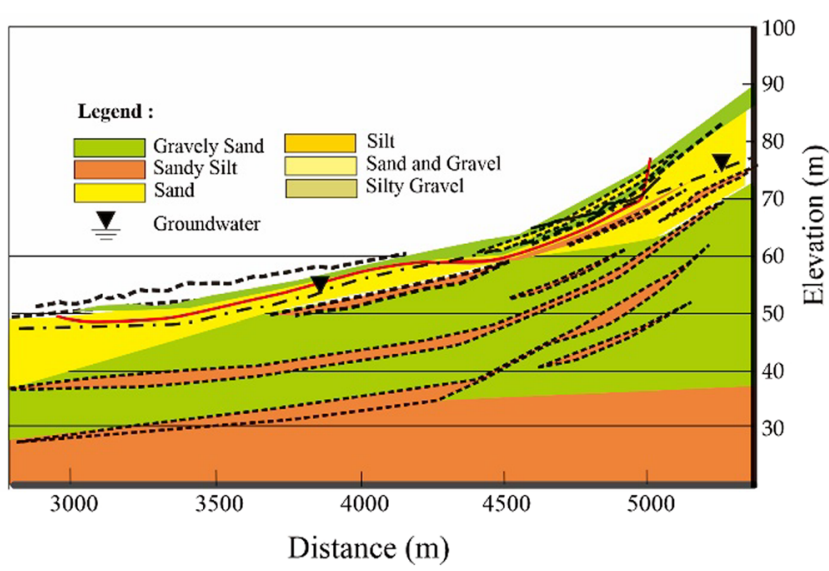

(b) cross-section in area mudflows of Jono Oge

Fig. 13 Geological profile proposed (modified from JICA 2019) after earthquake 2018 
Table 6 The runoff of water effects flash flood in Palu area

\begin{tabular}{|c|c|c|c|c|c|c|c|}
\hline $\begin{array}{l}\text { Vertical of } \\
\text { permeability, } k \\
(\mathrm{~cm} / \mathrm{s})\end{array}$ & $\begin{array}{l}\text { Different in } \\
\text { height, } h(\mathrm{~cm})\end{array}$ & Distance, I (cm) & Velocity, $v(\mathrm{~cm} / \mathrm{s})$ & $K$ & $\begin{array}{l}\text { Catchment } \\
\text { area, } A\left(\mathrm{~cm}^{2}\right)\end{array}$ & $\begin{array}{l}\text { The runoff of } \\
\text { water, } Q\left(\mathrm{~cm}^{3} / \mathrm{s}\right)\end{array}$ & Location \\
\hline $3.5 \times 10^{-3}$ & 1600 & $2.0 \times 10^{5}$ & $2.8 \times 10^{-5}$ & 1.0 & $0.40 \times 10^{6}$ & 11.20 & Balaroa \\
\hline $3.5 \times 10^{-3}$ & 1600 & $7.0 \times 10^{5}$ & $8.0 \times 10^{-6}$ & 1.0 & $1.43 \times 10^{6}$ & 11.44 & Petobo \\
\hline $3.5 \times 10^{-3}$ & 1600 & $6.7 \times 10^{5}$ & $8.4 \times 10^{-6}$ & 1.0 & $1.35 \times 10^{6}$ & 11.28 & Jono Oge \\
\hline
\end{tabular}

in Table 6. The vertical permeability coefficient used in the calculations is based on the results of a field survey by JICA (2019). Therefore, the peak runoff of water flash floods for the Palu area could be calculated as the averaged value of the three locations from Table 6 . The result is $11.31 \mathrm{~cm}^{3} / \mathrm{s}$.

The saturated mudflow material contained water that was equal to or higher than the liquid limit. Mudflow is a viscous liquid state with the criteria within the ratio of the average width and length of the soil mass movement, which ranges from 0.05 to 0.3 (Liu and Mason 2009). Meanwhile, the mudflow ratio in Palu City ranged from 0.2 to 0.4 . However, there was some accordance between the (Liu and Mason 2009) criteria and the mudflow event in the Palu region. Meixler (2018) reported that the shaking of the earthquake generated the loose material to become wave-like mudflows and move down the slope was responsible for the massive damage in the Palu area.

The landslide that turned into mudflows in Balaroa was tremendously influenced by a 3-5 m displacement of the total length of the $140 \mathrm{~km}$ of Palu Koro fault Valkaniotis et al. (2018). The morphology mapping of landslides in Balaroa was impacted by secondary fault strands, which resulted in erosion. Furthermore, the major mudflow in Balaroa damaged the residential communities of the main downstream. The two landslide flows in Petobo and Jono Oge in the Palu basin were underwent an enormous land deformation. However, the most significant land displacement scale was taken place in Jono Oge village Hazarika et al. (2021).

The displacement pattern of the area after the earthquake was able to be clearly defined. The rice cultivation area experienced displacement of more than $5 \mathrm{~m}$ was affected by the Gumbasa irrigation channel damage and the rice planting scheme at the local location, which raised the groundwater level (Bradley et al. 2019). Based on the rational method approach, the average runoff peak at the Balaroa, Petobo, and Jono Oge locations is presented in Table 6.

The limitations of this study in determining the water runoff induced by the flash floods during the Palu earthquake required further research. Groundwater depth position data was used to predict the emergence of runoff peaks which were assumed to be the same in all areas.

\section{Conclusions}

This study presents a liquefaction analysis of the $7.5 M_{\mathrm{w}}$ earthquake in Palu, Indonesia, on September 28, 2018. The phenomenon of massive liquefaction led to mudflows in the Balaroa, Petobo, and Jono Oge areas. Microtremor and N-SPT seismic measurements were carried out to determine the soil susceptibility to the dynamic influence of the command area.

Liquefaction is controlled by the geological formation of alluvial deposits that are dominated by gravel sand and muddy sand. The Balaroa liquefaction was the only failure observed in the north to the south side of the Palu valley. The displacement of the Balaroa slope, which was most likely caused by a secondary strand fault movement, triggered mudflow. As Petobo and Jono Oge areas are located on the western slope of the Gumbasa irrigation channel, the water flow on the channel also accelerated the emergence of mudflows through the ground fractures. It can be concluded that the average peak of water runoff causing the mudflow was approximately $11.31 \mathrm{~cm}^{3} / \mathrm{s}$.

The shaking of the 2018 earthquake affected the softening of the soil layer and consequently produced liquefaction in the Balaroa, Petobo, and Jono Oge regions since the areas have shallow groundwater levels. Liquefaction occurence in Balaroa could be confirmed by using the semi-empirical analysis and susceptibility index approach from the microtremor survey. The result indicates that liquefaction can occur at a maximum depth of $16 \mathrm{~m}$ below ground level.

The depth of liquefaction was found at $16 \mathrm{~m}$ below the ground surface. The N-SPT and microtremor seismic susceptibility index data indicate a significant factor of the deposited soil layer on the response susceptibility and manifestation of liquefaction damage.

Flow liquefaction in Balaroa, Petobo, and Jono Oge was strongly influenced by the presence of alluvial soil deposits and shallow groundwater levels prior to the earthquake shocks. Alluvial deposits are considered as contractive behavior in areas with low density or penetration resistance $\left(N_{1}\right)_{60}$, which is called flow liquefaction. 


\begin{abstract}
Abbreviations
BMKG: The Meteorological, Climatological, and Geophysical Agency; $M_{w}$ : Moment magnitude; LPI: Liquefaction potential index; N-S: North-South; NNW-SSE: North Northwest-South Southeast; $R_{e}$ : Epicenter distance; $H / V$ : Horizontal/vertical; $f_{p}$ : Dominant frequency; $A_{p}$ : Amplification factor; $S_{\mathrm{u}}:$ Undrained shear strain; SPT: Standard penetration test; N-SPT: Number-standard penetration test; PGA: Peak ground acceleration; CRR: Cyclic resistance ratio; CSR: Cyclic stress ratio; GWL: Groundwater level; f: Frequency; A: Amplitude; $F S_{\text {Liq }}$ : Factor of safety against liquefaction.
\end{abstract}

\section{Acknowledgements}

The authors would like to express their gratitude for the support given by the Indonesian Endowment Fund for Education, as well as the Ministry of Research, Technology, and Higher Education.

\section{Authors' contributions}

"AJ performed the analysis data and experiments. TFF (promotor) supervised the work, partially conducted the data analysis as well as provided guidance in composing the liquefaction framework. IS (Co-Promotor) provided guidance in working with liquefaction and data analysis, WW (Co-Promotor) as geologist, helped with a guidance in the mechanism of geological hazard analysis procedure. All authors read and approved the final manuscript."

\section{Funding}

The research was fully funded by Indonesian endowment fund for education.

\section{Availability of data and material}

The datasets generated during and/or analysed during the current study are available in the Jalil et al. (2020): Liquefaction in Palu: The Cause of Massive Mudflows. figshare. Dataset. https://doi.org/10.6084/m9.figshare.13476729.v1

\section{Declarations}

\section{Competing interest}

The authors declare no conflict of interest.

\section{Author details}

'Department of Civil and Environmental Engineering, Faculty of Engineering, Universitas Gadjah Mada, Yogyakarta 55281, Indonesia. ${ }^{2}$ Department of Geological Engineering, Faculty of Engineering, Universitas Gadjah Mada, Yogyakarta 55281, Indonesia. ${ }^{3}$ Center for Disaster Mitigation and Technological Innovation (GAMA-InaTEK), Universitas Gadjah Mada, Yogyakarta 55281, Indonesia. ${ }^{4}$ Department of Civil Engineering, Faculty of Engineering, Universitas Malikussaleh, Aceh 24355, Indonesia.

\section{Received: 22 December 2020 Accepted: 11 August 2021}

Published online: 24 August 2021

\section{References}

Ambraseys NN (1988) Engineering seismology: part II. Earthq Eng Struct D 17(1):51-105. https://doi.org/10.1002/eqe.4290170102

Araujo W, Ledezma C (2020) Factors that affect liquefaction-induced lateral spreading in large subduction earthquakes. Appl Sci 10(18):1-21. https:// doi.org/10.3390/app10186503

BMKG (2018) Study of seismic parameters in the Palu region and surrounding areas. Available online: https://docplayer.info /110191815-Kajian-parameter-kerentanan-seismik-wilayah-kota-palu-dan-sekitar-nya. Accessed on 4 April 2020 (in Indonesia)

Bradley K, Mallick R, Andikagumi H, Hubbard J, Meilianda E, Switzer A, Du N, Brocard G, Alfian D, Benazir FG, Yun SH, Majewski J, Wei S, Hill EM (2019) Earthquake-triggered 2018 Palu valley landslides enabled by wet rice cultivation. Nat Geosci 12(11):935-939. https://doi.org/10.1038/ s41561-019-0444-1

Faris F, Fathani TF, Wang F (2019) Report on the UNESCO Chair workshop on geoenvironmental disaster reduction 28th April-1st may, 2019, PaluJakarta, Indonesia. Geoenviron Disasters 6(12):1-6. https://doi.org/10. 1186/s40677-019-0129-5
Fathani TF, Legono D, Karnawati D (2017) A numerical model for the analysis of rapid landslide motion. Geotech Geol Eng 35(5):2253-2268. https://doi. org/10.1007/s10706-017-0241-9

Fear CE, Robertson PK (1995) Estimating the undrained strength of sand: a theoretical framework. Can Geotech J 32(5):859-870. https://doi.org/10. 1139/t95-082

Geotechnical Control Office (1984) Geotechnical Manual for Slopes. 2nd Ed. Engineering Development Department Hongkong

Hazarika H, Rohit D, Pasha SMK, Maeda T, Irsyam M, Arsyad A, Nurdin S (2021) Large distance flow-slide at Jono-Oge due to the 2018 Sulawesi earthquake, Indonesia. Soils Found 61(1):239-255. https://doi.org/10.1016/j. sandf.2020.10.007

Idriss IM, Boulanger RW (2008) Soil liquefaction during earthquakes. MNO-12, EERI Publications, United Stated of America, Earthquake. Engineering Research Institute, 2008, 1-264

Irsyam M, Hanifa NR, Djarwadi D, Sarsito DA, Widiyantoro S, Natawidjaja D, Meilano I, Rudyanto A, Hidayati S, Triyoso W, Faizal L, Sunarjito (2019) The seismic source and hazard map of Indonesia 2018 National Center for Earthquake Study (PUSGEN)

Ishihara K (1996) Soil behaviour in earthquake geotechnics. Oxford Engineering Science Series 45. Oxford University Press, Oxford

Ishihara K (2019) Flow and lateral spreads of liquefied ground following earthquakes. International conference on landslides and slope stability, Sept. 26-28, 2019, Bali, Indonesia

Iwasaki T, Tokida K, Tatsuoka F (1981) Soil liquefaction potential evaluation with use of the simplified procedure. In: Proceedings of the first international conference on recent advances in Geotechnical Earthquake Engineering and Soil Dynamic, April 26 - May 3, St. Louis, Missouri

Jalil A, Fathani TF, Satyarno I, Wilopo W (2020) A study on the liquefaction potential in Banda Aceh City after the 2004 Sumatera earthquake. Int J GEOMATE 18(65):147-155. https://doi.org/10.21660/2020.65.94557

JICA (2019) Project report, the project for development of regional disaster risk resilience plan in Central Sulawesi

Keefer DK (1994) The importance of earthquake-induced landslides to longterm slope erosion and slope-failure hazards in seismically active regions. Geomorphology 10(1-4):265-284. https://doi.org/10.1016/0169-555X(94) 90021-3

Li XS, Ming HY (2000) Unified modeling of flow liquefaction and cyclic mobility. Soil Dyn Earthq Eng 19(5):363-369. https://doi.org/10.1016/S02677261(00)00022-1

Liu JG, Mason PJ (2009) Essential image processing and GIS for remotes sensing. Wiley-BlackWell, London

Mase LZ, Likitlersuang S, Tobita T (2020) Verification of liquefaction potential during the strong earthquake at the border of Thailand Myanmar. J Earthq Eng. https://doi.org/10.1080/13632469.2020.1751346

Mason H B, Gallant A, Hutabarat D, Montgomery J, Reed A N, Wartman J, Irsyam M, Prakoso W, Djarwadi D, Harnanto D, Alatas I, Rahardjo P, Simatupang P, Kawanda A, Hanifa R (2019) The 28 September 2018 M7.5 Palu-Donggala, Indonesia earthquake: Version 1.0 geotechnical extreme events reconnaissance association report GEER-061. https://doi.org/10. $18118 / \mathrm{g} 63376$

Meixler E (2018) How liquefaction made flow like wave in Indonesia's earthquake disaster. TIME https://time.com/5413507/liquefaction-indonesiaearthquake-damage. Accessed on 23 September 2020

Miyajima M, Setiawan H, Yoshida M, Ono Y, Kosa K, Oktaviana I S (2019) Geotechnical damage in the 2018 Sulawesi earthquake, Indonesia. Geoenviron Disasters 6(6):1-8. 10/1186/s40677-019-0121-0

Naing M T, Fathani T F, Wilopo W (2018) Estimating the velocity of landslide movement using visco-plastic model in Jeruk Sub-village, Kulon Progo District, Yogyakarta, Indonesia. JCEF 4(3): 276-282. https://doi.org/10. 22146/jcef.35097

Nakamura Y (1989) A Method for dynamic characteristics estimation of subsurface using microtremor on the ground surface. Q Report Railway Tech Res Inst 30(1):25-33

Nakamura Y (1997) Seismic vulnerability indices for ground and structures using microtremor. World Congress on Railway Research in Florence, Italy

Nakamura Y (2000) Clear identification of fundamental idea of Nakamura's technique and its applications. In: Proceedings of the 12th world conference on earthquake engineering, New Zealand, Paper No. 2656 
Olson SM, Stark TD (2003) Yield strength ratio and liquefaction analysis of slopes and embankments. J Geotech Geoenvironmental Eng 129(8):727737. https://doi.org/10.1061/(ASCE)1090-0241(2003)129:8(727)

Robertson PK (2010) Evaluation of flow liquefaction and liquefied strength using the cone penetration test. J Geotech Geoenviron Eng 136(6):842853. https://doi.org/10.1061/(ASCE)GT.1943-5606.0000286

Robertson I, Mulchandani H K, Achiari H, Esteban M, Mikami T, Nakamura R, Shibayama T, Stolle J, Takabatake (2019) Palu earthquake and tsunami, Sulawesi, Indonesia: Field Assessment Team 1 (FAT-1) Early Access Reconnaisssance Report (EARR). NHERI DesignSafe Project ID: PRJ-2128. https:// doi.org/10.17603/DS2XD5S

Sadly M (2018) Gempa Tektonik M=7,7 Kabupaten Donggala, Sulawesi Tengah pada Jumat 28 September 2018, Berpotensi Tsunami. BMKG. https://www.bmkg.go.id/press-release/?p= gempabumi-tektonikm7-7-kabupaten-donggala-sulawesi-tengah-pada-hari-jumat-28-september-2018-berpotensi-tsunami\&tag. Accessed on 22 January 2020 (in Indonesia)

Sato T, Nakamura Y, Saita J (2008) The change of the dynamic characteristics using microtremor. In: Proceedings of the World Conference on Earthquake Engineering. Beijing, China

SESAME (2004) Guidelines for the implementation of the H/N spectral ratio technique on ambient vibrations measurements, processing and interpretation. SESAME European Research Project WP12, deliverableno. D23.12. http://sesame-fp5.obs.ujf-grenoble.fr/Delivrables/Del-D23-HV_ User_Guidelines.pdf. Accessed on 28 march 2020

SNI 03-1726-2019 (2019) Earthquake resistance planning ordinance for building structures and non-building. national standardization agency of Indonesia (in Indonesia)
Socquet A, Hollingsworth J, Pathier E, Bouchon M (2019) Evidence of supershear during the 2018 magnitude 7.5 Palu earthquake from space geodesy. Nat Geosci 12:192-199. https://doi.org/10.1038/s41561-018-0296-0

Sukamto R (1973) Reconnaissance geological map of Palu area, Sulawesi. Scale 1:250.000. Geological Survey of Indonesia, Bandung, Indonesia

Syah A, Fathani TF, Faris F (2019) A Numerical analysis of landslide movements considering the erosion and deposition along the flow path. JCEF 5(3): 187-200. https://doi.org/10.22146/jcef.43808

Thein PS, Pramumijoyo S, Brotopuspito KS, Kiyono J, Wilopo W, Furukawa A Setianto A (2014) Estimation of seismic ground motion and shaking parameters based on microtremor measurements at Palu City, Central Sulawesi Province, Indonesia. World Acad Sci Eng Technol Int J Geol Environ Eng 8:308-319. https://doi.org/10.5281/zenodo.1092938

Thien PS (2015) Analysis of strong ground motion based on microtremors, boreholes and trench data in Palu City, Central Sulawesi Province, Indonesia. Dissertation, Universitas Gadjah Mada

Valkaniotis S, Ganas A, Tsironi V, Barberopoulou A (2018) A preliminary report on the M7.5 Palu earthquake Co-seismic ruptures and landslides using image correlation techniques on optical satellite data. Zenodo. https:// doi.org/10.5281/zenodo.1467128

Widyaningrum R (2012) Indonesian Geological Agency, Geological investigation of potential liquefaction Engineering in Palu Central Sulawesi Province: Ministry of Energy and Mineral Resources, Geological Agency. Rep. No: 297/LAP-BGE.P2K/2012 (in Indonesia)

\section{Publisher's Note}

Springer Nature remains neutral with regard to jurisdictional claims in published maps and institutional affiliations. 